\title{
Inkunabuły w zbiorach Biblioteki Opactwa oo. Cystersów w Szczyrzycu. Zarys problematyki
}

B iblioteka i Archiwum Opactwa OO. Cystersów w Szczyrzycu - poza kilkoma przyczynkarskimi artykułami, dotąd właściwie naukowo nie zbadana, wiąże się, z dziejami samego Opactwa w sposób historycznie nierozerwalny.Dzieje biblioteki, narastania jej zbiorów w ciagu wieków, oraz zasobności i znaczenia dla kultury polskiej, są przedmiotem badań autorki niniejszego opracowania, z zamiarem wydania w przyszłości obszernej monografii tej niezwykłej librarii. ${ }^{1}$

Biblioteka szczyrzycka zasobna w cenne średniowieczne pergaminy z I połowy XIII wieku, rękopiśmienne księgi, pięknie zdobione antyfonarze i graduały, pośród wcale pokaźnego zasobu starych druków, przechowuje również w swoich zbiorach, pierwsze zabytki sztuki drukarskiej, które w nauce noszą miano inkunabułów. [!]

Kolekcja inkunabułów Biblioteki Opactwa oo. Cystersów w Szczyrzycu, liczy 77 pozycji bibliograficznych w 51 woluminach.

Wydany w 1970 roku Centralny Katalog Inkunabulów w Bibliotekach Polskich w opracowaniu Marii Bohonos i Elizy Szandorowskiej, pod redakcją prof. Alodii Kaweckiej-Gryczowej, pośród kilkudziesięciu polskich bibliotek, które moga poszczycić się w swoich zbiorach kolekcją inkunabułów, wymienia również bibliotekę Opactwa oo. Cystersów w Szczyrzycu. ${ }^{2}$ Inkunabuły szczyrzyckie zostały po raz pierwszy ujęte w opracowaniu poświęconym zasadniczo bibliotece i zbiorom opactwa cysterskiego w Mogile. Opracowany przez cystersa, o. Gerarda Kowalskiego Katalog Inkunabutów Biblioteki Opactwa Mogilskiego oraz Katalog Inkunabułów Biblioteki Klasztoru Cystersów w Szczyrzycu został wydany w Krakowie, nakładem Akademii Umiejętności w 1915 r. Od tego momentu minęło ponad 80 lat. Długi to czas, w którym wiedza o starej, zabytkowej księdze poczyniła wielkie kroki ku przodowi, dając w pełni podstawę, by opracowane dotąd katalogi inkunabułów i starych druków, zweryfikować w oparciu o nowe osiagnięZ Badań Nad Polskimi Księgozbioram Historycznymi t. 21, Warszawa 2003 
cia naukowe $\mathrm{z}$ możliwością ich uzupełnienia i ponownego wydania. Autor wspomnianego już katalogu z 1915 r., o. Gerard Kowalski, we wstępie do swojej pracy zanotował takie oto zdanie: (...), Z dawnego archiwum klasztoru szczyrzyckiego niewiele zostalo, a biblioteka bardzo ucierpiala gdyż w roku 1794 rękopisy i znacznq część druków wywieziono do Lwowa i wcielono wraz z innemi po zniesionych w calym kraju klasztorach do biblioteki uniwersyteckiej, gdzie podczas pożaru w r. 1848 splonęty. Część biblioteki przewieziono do tarnowskiego seminaryum duchownego"3. Informacja powyższa znacznie mija się z prawdą historyczną a została ona oparta na artykule J. Łepkowskiego i J. Jerzmanowskiego zatytułowanym: Ułamek z podróży archeologicznej odbytej po Galicji w roku $1849 . .{ }^{4}$. Niestety nie jest ona udokumentowana żadnym zachowanym wiarygodnym źródłem historycznym, zaś do dzisiaj jest nadal cytowana i przytaczana w wielu opracowaniach tyczących się Szczyrzyca nie wyłączając skądinąd znakomitej monografii poświęconej cystersom polskim, pt.: Monasticon Cisterciense Poloniae T. 1-2, wydanej przez Zespół do Badań nad Historią [!] Kulturą Cystersów w Polsce, przy Instytucie Historii Uniwersytetu im. Adama Mickiewicza w Poznaniu. W rozdziale poświęconym bibliotekom klasztornym opactw cysterskich na ziemiach dawnej Rzeczypospolitej, w krótkim zaledwie zarysie zasobności, a nie historii biblioteki szczyrzyckiej, została podana informacja bez uprzedniego sprawdzenia, iż ,jakoby ksieggi szczyrzyckie trafity do zbiorów biblioteki seminaryjnej w Tarnowie"s.

A zatem autorka niniejszego opracowania, czuje się w obowiązku podać sprostowanie do tej informacji, które, jak należy mieć nadzieję, wyjaśni w pełni istotne niedomówienia historyczne co do zaistniałych wcześniej faktów.

Wspomniany Katalog Inkunabulów Biblioteki opactwa Mogilskiego... w opracowaniu o. Gerarda Kowalskiego był już przedmiotem rozważań naukowych znakomitego polskiego inkunabulisty okresu międzywojennego, Kazimierza Piekarskiego. ${ }^{6}$

We wstępie do Uwag... Piekarski, nie omieszkał zaznaczyć, iż (...) ,sporzqdzony przez śp. ks. Gerarda Kowalskiego [katalog - przyp. J. M. M.], pod okiem śp. dr Józefa Korzeniowskiego, co chociaż $w$ druku nie jest zaznaczone, trzeba podać do wiadomości" (...) ${ }^{7}$, pisał dalej, iż: (...) ,Powodem obszernych uwag, jakie poniżej zamieszczamy, jest szereg pochlebnych, a wcale nie wyczerpujacych ocen i sprawozdań poświęconych temu katalogowi. Wysunięte $w$ jednej z nich stwierdzenie, że jest on „pracq wypetniana wzorowo", niestety, będziemy niejednokrotnie niżej wykazać, że pracy tej 
właśnie za wzór brać się nie powinno. Wskazujac jednak przede wszystkim na strony ujemne, nie mamy wcale zamiaru odmawiać śp. Autorowi zastug w tak zaniedbanej u nas dziedzinie badań, jaka jest inkunabulistyka, idzie raczej o to, by uwagi niniejsze dopelnity jego pracę, która często brać będzie w ręce z pożytkiem polski bibliograf $i$ historyk kultury."

Kazimierz Piekarski, podkreślając wielokrotnie niezaprzeczalne znaczenie, jakie już wówczas dla kultury polskiej książki miało ukazanie się takowego opracowania, nie podważał jego znaczenia historycznego. Wykazanie przez uczonego błędów i uchybień, których nie ustrzegł się Gerard Kowalski, w niczym nie umniejsza znaczenia jego publikacji dla dalszego poznania dziejów polskiej książki drukowanej. Jeśli zważymy, iż o. Gerard Kowalski, zakonnik cysterski, a zapewne archiwista i historyk, bez specjalistycznych studiów inkunabulistycznych, podjął się tak ważnego dla nauki polskiej przedsięwzięcia, jakim było opracowanie w formie katalogu, inkunabułów mogilskich i szczyrzyckich, to niewątpliwie musimy dojść do wniosku, iż było to przedsięwzięcie godne najwyższego uznania. Mamy, bowiem w tym przypadku do czynienia z ogromnym trudem, jakim była „rejestracja” i opis inkunabułów. Autor bowiem nie dysponował wszystkimi znanymi wówczas bibliografiami, które opisywały inkunabuły według obowiązujących kryteriów naukowych. Idąc dalej w niniejszych rozważaniach, nie wolno pominąć faktu, iż większość zasobnych przez wieki bibliotek klasztornych ogromne poniosła zniszczenia w okresie zaborów. Stare zakonne librarie ulegały w znakomitej większości całkowitemu zniszczeniu i rozproszeniu. W chwili obecnej nie można nawet podjąć próby ich teoretycznego odtworzenia, gdyż w wielu wypadkach nie zachowały się spisy, czy inwentarze ksiąg będące ich miarodajną podstawą. W obliczu takich strat dla kultury i nauki polskiej, jakiej „,dokonały ostatnie trzy wieki”, w zasobności klasztornych bibliotek, Katalog Kowalskiego, mimo niewątpliwych uchybien ${ }^{9}$ naukowych, nie tylko spełnił rolę historyczną będąc rejestrem najstarszych ksiag opactwa Cystersów w Mogile koło Krakowa i „oddalonego nieco od świata" opactwa Cystersów w Szczyrzycu. Był i nade wszystko jest do dzisiaj niezwykle ważnym dokumentem archiwalnym. Bowiem po upływie ponad osiemdzieięciu lat, można nadal skonfrontować oba zasoby inkunabułów ze stanem obecnym na półkach. Uzupełnić braki bądź błędy, które zostały ongiś popełnione, podjać się żmudnej pracy związanej z odczytywaniem wpisów proweniencyjnych, not marginalnych, dokonać opisu opraw druków piętnastowiecznych, uzupełnić w opisie inkunabułów brakujące bibliografie, na brak których w okresie mię- 
dzywojennym zwrócił już uwagę Kazimierz Piekarski. Opisy inkunabułów można przede wszystkim obecnie skonfrontować z wydanym w 1970 roku, Centralnym Katalogiem Inkunabułów w Bibliotekach Polskich. Wszak przez blisko sto lat, wiedza nasza o tak wąskiej dziedzinie wiedzy, jaką jest inkunabulistyka, niepomiernie wzrosła dzięki badaniom znakomitych polskich i zagranicznych uczonych.

Przedmiotem badań autorki niniejszego katalogu jest zbiór inkunabułów znajdujący się obecnie w bibliotece opactwa oo. Cystersów w Szczyrzycu. Został on skrupulatnie skonfrontowany z Katalogiem Gerarda Kowalskiego oraz wspomnianym Centralnym Katalogiem Inkunabulów w Bibliotekach Polskich i obecnie jest przygotowywany do druku.

Opiekujący się kilkadziesiąt lat biblioteką szczyrzycką śp. o. Antoni Gucwa, odnotowywał również skrzętnie swoje uwagi na marginesie Centralnego Katalogu Inkunabułów. Spostrzeżenia swoje zamieszczał przy kolejnych numerach wspomnianego Katalogu, które rejestrowały inkunabuły w Szczyrzycu, jednocześnie konfrontując je z Katalogiem Kowalskiego. Przy kilku pozycjach w IBP, o. Antoni odnotował m.in. brak ujęcia inkunabułu w $\mathrm{Ka}$ talogu, mimo, iż znajdował się on na półkach biblioteki klasztornej. ${ }^{10}$

Dzięki dociekliwości i skrupulatności o. Antoniego Gucwy, można niejako „dalej prześledzić" losy szczyrzyckich inkunabułów. I tak z poz. 40 obecnego katalogu [Iacobus de Voragine, Legenda aurea, 1486] wiąże się niewyjaśnione, chwilowe zaginięcie woluminu, którego rzeczywiście w chwili ,centralnego spisu” w latach sześćdziesiątych, nie było w bibliotece. Był on ujęty pod poz. 45 w Katalogu Kowalskiego. Świadczy o tym notatka, która zachowała się w zbiorach archiwum biblioteki opactwa, informująca, iż ,inkunabul zostal odzyskany przez opactwo w 1966 r., za pośrednictwem Biblioteki Jagiellońskiej z jednego z antykwariatów krakowskich"'l.

Przykład powyższy zdaje się dobitnie podkreślać raz jeszcze znaczenie Katalogu Kowalskiego dla zbiorów librarii szczyrzyckiej, z możliwością dalszego konfrontowania i sprawdzania tego, co ostało się jeszcze na półkach biblioteki. Zapewne przez nieuwagę nie został ujęty w Centralnym Katalogu Inkunabulów, druk, który choć figuruje pod poz. 52 w Katalogu Kowalskiego - nie został zamieszczony w IBP pod poz. 2412. Są to jednak „drobiazgi”, które można w pełni sprawdzić w obu katalogach, wyciagając chyba najważniejszy wniosek dla historyka, iż owa konfrontacja książki piętnastowiecznej, jest nadal możliwa dzięki szczególnej dbałości o spuściznę minionych pokoleń, którą zawdzięcza się kilku niestrudzonym bibliotekarzom zakonnym. Ale zdarzały się sytuacje odwrotne. Zespól badaczy Biblioteki 
Narodowej, po przeglądnięciu, zasobów książki piętnastowiecznych w bibliotece szczyrzyckiej „odnalazł” inkunabuły, których o. Gerard Kowalski $z$ niewiadomych przyczyn nie ujął w sporządzonym przez siebie katalogu ${ }^{12}$. Wszystkie te wnioski, które nasuwały się przy konfrontowaniu obu katalogów ${ }^{13}$, wypływały niejako same $\mathrm{z}$ siebie, a uwzględnione dalsze postulaty badawcze wysunięte i mocno podkreślone przez Kazimierza Piekarskiego, spowodowały potrzebę ponownego opracowania Katalogu piętnastowiecznych druków Biblioteki Opactwa oo. Cystersów w Szczyrzycu.

\section{CHARAKTERYSTYKA SZCZYRZYCKICH INKUNABUŁÓW I. DRUKI NAJSTARSZE I RZADKIE}

Inkunabuły Biblioteki opactwa oo. Cystersów w Szczyrzycu są historyczną kolekcją starych ksiąg, które gromadzone przez kolejne pokolenia klasztornych bibliotekarzy, światłych opatów czy szczodrobliwych darczyńców, przetrwały na półkach klasztornej biblioteki do naszych czasów, dając niewątpliwe świadectwo umysłowości i potrzeb duchowo - intelektualnych minionych pokolen. Zachowany zbiór piętnastowiecznych druków szczyrzyckich pod wieloma względami należy do bardzo interesujących. Dotyczy to zarówno samych autorów, jak i tematyki ksiag, bardzo ciekawych wpisów proweniencyjnych, glos marginalnych czynionych na czystych kartkach, bądź marginesach poszczególnych woluminów, niektórych opraw, zdobnictwa, a także ,przeglądu” topograficznego poszczególnych oficyn wydawniczych, z których pochodziły opisywane inkunabuły.

Wśród nich znajduje się najstarsze zachowane w zbiorach szczyrzyckich dzieło. Jest to Margarita Davidica seu Expositio Psalmorum pochodząca z augsburskiej typografii Güntera Zainera, datowana w przybliżeniu na około $1475 / 1476 \mathrm{r}^{14}$ Dzieło zawiera oczywiście proweniencję szczyrzycką z dobrze zachowanym wpisem własnościowym: „Ex libris Fratrum Monasterij Ciricensis", pochodzącym z II połowy XVII wieku. Wtedy to po raz pierwszy przeprowadzono inwentaryzację biblioteki, sygnując poszczególne egzemplarze wyżej wspomnianym wpisem, widniejącym na wszystkich bez mała woluminach. Wpis swój odręczny na tymże woluminie postawił również Jan Kajetan Bańkowski, cysters, który przez krótki czas, pośród rozlicznych obowiązków pełnił funkcję kustosza zbiorów bibliotecznych w Szczyrzycu. ${ }^{15}$

Do grupy najstarszych inkunabułów bez wątpienia zaliczyć trzeba: Breviloquium Św. Bonawentury, pochodzące $\mathrm{z}$ augsburskiej typografii Anto- 
niego Sorga, datowane w przybliżeniu na około 1476 rok [! $]^{16}$ Dzieło to zawiera interesującą notę proweniencyjną wskazującą iż zapewne wcześniej niż w bibliotece szczyrzyckiej, było ono w posiadaniu pierwszej a zarazem najstarszej parafii prowadzonej przez cystersów szczyrzyckich - Górze Św. Jana ${ }^{17}$, którą w przeszłości nazywano „Górą Szczyrzycką”. Również z 1476 r. pochodzi kolejne dzieło, którego autorstwo jest ,przypisywane" Pseudo-Bonawenturze, jest to Speculum Beatae Mariae Virginis, wydane również w Augsburgu przez Antoniego Sorga. W tym przypadku mamy podaną już dokładną datę ukończenia druku, która przypadła na 29 II 1476 $\mathrm{r}^{18}$. W tej niewielkiej grupie ,najstarszych" inkunabułów, które przechowuje biblioteka szczyrzycka, znajduje się również ciekawy druk, podobnie jak i poprzedni, pochodzący z typografii Antoniego Sorga [in Monasterio ss. Udalrici et Afrae] datowany na 1476 rok jest to Jana de Peckham - De oculo morali. Cum Tabula Matthiae deVienna ${ }^{19}$.

W grupie ,najstarszych” inkunabułów, zwraca uwagę fakt, iż wszystkie pochodzą z Augsburga, z typografii Antoniego Sorga i również wszystkie, jako datę ukończenia druku przyjmują rok 1475/1476. A zatem nasuwa się pytanie, czy było to dziełem przypadku, że właśnie z jednego ośrodka wydawniczego, od jednego typografa i właściwie z jednego roku pochodzą cztery inkunabuły szczyrzyckie, które pośród 77 uznać można za najstarsze względem pozostałych. Być może na to pytanie będzie można dać choćby częściową odpowiedź, po dokładnym zapoznaniu się z dokumentami archiwalnymi, w których zawarte są wzmianki dotyczące sposobu, czasu i okoliczności „nabywania” piętnastowiecznych druków do biblioteki klasztornej.

Niestety w przechowywanym zasobie szczyrzyckich inkunabułów zabrakło poloniców typograficznych, a zatem próżno by szukać Krakowa, Wrocławia, Gdańska, czy Chełmna nad Wisła.

Godnym odnotowania jest fakt, iż wśród zgromadzonych inkunabułów Biblioteki Opactwa oo. Cystersów w Szczyrzycu znajduje się kilka druków unikatowych w skali kraju ${ }^{20}$. Są także trzy pojedyncze egzemplarze ${ }^{21}$, które IBP odnotowuje jedynie w bibliotece szczyrzyckiej, są to: Officium Beatae Mariae Virginis, druk wydany w Wenecji przez Jana de Hallis w 1486 r., typografa, który „reprezentowany” jest tylko raz w Centralnym Katalogu Inkunabułów Polskich ${ }^{22}$, jako drukarz tego właśnie dziełka oraz Psalterium, Lat., cum canticis et hymnis, druk prawdopodobnie wydany w Norymberdze, przez oficynę, używającą określenia „Typographus Legendae s. Rochi” około 1482 r. Z typografii tej poza wymienionym dziełem, biblioteki polskie posia- 
dają w swoich zbiorach tylko jeden inkunabut ${ }^{23}$. Ten unikatowy druk zwraca uwagę nie tylko niewielkim formatem - tzw. dwunastka bibliograficzna - ale również oprawą wpisami proweniencyjnymi, licznymi uzupełnieniami tekstu drukowanego i nieco ,nieporęcznym”, by nie rzec, niedbałym zdobnictwem marginesów dziełka. W niczym to jednak nie umniejsza faktu, iż w zbiorach bibliotek polskich, które w swoim spisie ujął Centralny Kata$\log \ldots$, Psalterium... odnotowane jest jedynie w Bibliotece Opactwa oo. Cystersów w Szczyrzycu. O. Gerard Kowalski, w swoim katalogu jako istotną uwagę odnoszącą się do tego druku zamieścił m.in. informację tej treści "(...) Egzemplarz bardzo defektowny, którego brakujace karty zastapiono białemi i dopisano brakujacy tekst." ${ }^{24}$. Wreszcie ostatnim z pośród trzech unikatowych inkunabułów jest: Regimen Sanitatis Parisiense rhytmice ..., wydany w Lipsku, w typografii Melchiora Lottera 1 III $1[4] 99 \mathrm{r}^{25} \mathrm{z}$ nieodłącznym wpisem proweniencyjnym biblioteki szczyrzyckiej.

\section{POLONICA W ZBIORACH INKUNABUŁÓW SZCZYRZYCKICH}

Jak zostało już wspomniane, brak jest w zbiorze inkunabułów szczyrzyckich poloniców typograficznych, ujawnionych przez Bibliografię Polskq Estreichera. Zdumiewa nieco fakt, iż żaden z piętnastowiecznych woluminów nie pochodzi $z$ warsztatów drukarzy choćby krakowskich, zważywszy na udokumentowane kontakty zakonników szczyrzyckich z opactwem w Mogile, położonej niedaleko Krakowa. Czyżby, zatem łatwiej i taniej (?) można było przewieźć owe księgi z odległej Norymbergii, Lipska, Wenecji, czy Rzymu? A może z uwagi na oddalenie Szczyrzyca od głównych szlaków handlowo-komunikacyjnych było ongiś sporym utrudnieniem dla wędrownych sprzedawców ksiag, by odwiedzić to niewielkie opactwo rozlokowane w urokliwej dolinie rzeki Stradomki w Beskidzie Wyspowym, u stóp Cietnia? Być może istniały i inne racje, które z niewiadomych nam przyczyn spowodowały, że w Bibliotece szczyrzyckiej nie odnajdujemy ani jednego z piętnastowiecznych poloniców tzw. ,typograficznych". A zatem nic mogąc wskazać na żaden piętnastowieczny polonik wydawniczy, odnaleźć możemy w zbiorze najstarszych, drukowanych ksiag, ledwie kilka poloników piśmienniczych.

Poczet znamienitych autorów - mistrzów Akademii Krakowskiej „otwiera” wybitny uczony i wykładowca średniowiecznej filozofii: Jan Głogowczyk, którego dzieło: Exercitium super omnes tractatus Parvorum logicalium Petri Hispani... ${ }^{26}$, wydane w Lipsku, przez Wolfganga Stockela i Jana Hal- 
lera w 1500 r, możemy zaliczyć, do tzw. „poloniców piśmienniczych” szczyrzyckiej biblioteki. Ten niewielki zbiór „inkunabułów-poloniców” uzupełniają nazwiska wybitnych teologów i kaznodziejów kościoła: Mateusz z Krakowa ze swoim dziełem: Confessionale, sive de modo confitendi et puritate conscientiae (Erfurt, Typ. Aristeae, ca 1483) ${ }^{27}$, oraz Mikołaj z Błonia ze swoim dziełem De Sacramentis. Biblioteka klasztorna w Szczyrzycu zawiera dwa różne wydania tego druku, co prawda oba pochodzą ze Strasburga - lecz różnią je zasadniczo oficyny wydawnicze i rok ukończenia druku ${ }^{28}$. W stosunku do tych właśnie dzieł i ich autorów nastapił błąd w opisie Katalogu Kowalskiego. I tak Kowalski pod poz. 75, dziełu Confessionale ... przypisuje błędnie autorstwo św. Tomasza z Akwinu. Zostało to również wyjaśnione przez zespół badaczy Biblioteki Narodowej (por. IBP poz. 3647) zaś autorka niniejszego opracowania porównując z autopsji oba wydania De Sacramentis ... Mikołaja z Błonia, stwierdziła, iż opis proweniencji obu dzieł został pomylony przez o. Gerarda Kowalskiego. Kwestia ta została wyjaśniona i sprostowana po dokładnym sprawdzeniu obu inkunabułów. ${ }^{29}$

\section{OFICYNY WYDAWNICZE I AUTORZY SZCZYRZYCKICH INKUNABUŁÓW}

Mapa ośrodków drukarskich XV wieku, z których pochodzą inkunabuły szczyrzyckie obejmuje zasadniczo trzy kraje ówczesnej Europy: Niemcy, Włochy oraz Szwajcarię.

W ogólnej liczbie 77-u inkunabułów, reprezentowanych jest 16 ośrodków impresorskich piętnastowiecznej Europy. ${ }^{30} \mathrm{~W}$ tym stosunek ilościowy druków pochodzenia niemieckiego i włoskiego jest niepodważalny, do zaledwie trzech oficyn szwajcarskich (dawna Helvetia), reprezentowanych przez znamienity ośrodek w Bazylei.

Ogromny napływ książki pochodzenia niemieckiego thumaczy się w tym przypadku zapotrzebowaniem na literaturę religijną książki kościelne, mszały i brewiarze. A jak wiadomo Niemcy byli głównymi dostawcami Biblii, ksiag liturgicznych, dzieł teologicznych w duchu średniowiecznej scholastyki i literatury użytkowej. ${ }^{31}$ Impresorskie ośrodki niemieckic reprezentuje w zbiorze inkunabułów szczyrzyckich łącznie 12 miast. Bezsprzecznie prym wiodą: Strasburg - 6 oficyn wydawniczych, łącznie 13 druków, w tym najliczniej reprezentowana jest oficyna, która w literaturze przedmiotu nosi miano: „Typographus lordani = Georgius Husner" - 5 druków. Pozosta- 
łe oficyny strassbourskie reprezentowane są przez dwa bądź zaledwie przez jeden tytuł, m.in. np. Marcin Flach, Jan Grüninger, czy „Typographus Legendae Aureae". Norymberga - 5 oficyn wydawniczych, łącznie 15 druków, w tym najliczniej reprezentowana jest oficyna wydawnicza Antoniego Kobergera - 10 druków, Kaspra Hochfedera - 3 druki, Fryderyka Flacha - 2 druki. Pozostałe oficyny norymberskie, tj. Jerzy Stuchs i ,Typographus Legendae s. Rochi" - reprezentowane są przez pojedyncze druki. W Kolonii działały 4 oficyny wydawnicze, z których odnotowano łącznie 7 druków, w tym niekwestionowane pierwszeństwo przypada typografowi kolońskiemu Henrykowi Quentellowi - 4 druki, pozostali impresorzy to: Jan Koelhoff - Senior, Jan Landen i oficyna ,Retro Minores" (Marcina de Werdeny), których biblioteka szczyrzycka posiada po jednym druku. Lipsk - 3 oficyny wydawnicze, łącznie 5 druków z wyraźną przewagą oficyny Wolfganga Stöckela - 3 druki. Pozostali typografowie: Melchior Lotter i Konrad Kochelofen - zaledwie po jednym druku. Augsburg i Magdeburg - reprezentowany jest przez dwie oficyny wydawnicze działające w każdym z tych miast. Pozostałe ośrodki niemieckie, tj. Erfurt, Hagenau, Heidelberg, Reutlingen, Speyer i Tybinga, przez pojedyncze typografie.

A zatem jeśli się zważy, że na ogólną liczbę 77-u zarejestrowanych inkunabułów w bibliotece szczyrzyckiej, aż 58 woluminów wyszło spod pras typografów niemieckich, prymat drukarski ojczyzny Gütenberga jest niekwestionowany. Interesująco również wypada przegląd piętnastowiecznych druków niemieckich od strony tak autorów, jak i tematyki samych dzieł. Kolonia, oraz działające na jej terenie oficyny wydawnicze, zajmują wśród kilku ośrodków niemieckich ważne miejsce, będąc w omawianym okresic „,ostoją tradycyjnej teologii i filozofii" ${ }^{32}$

$\mathrm{Z}$ oficyn drukarskich Kolonii w bibliotece odnajdujemy m.in. dzieła greckiego filozofa Arystotelesa De Anima (1491) ${ }^{33}$, oraz Opera $(1497)^{34}$. Reprezentują scholastykę tego najbardziej konserwatywnego z uniwersytetów m.in. Gerardus de Harderwyck ze swoim dziełem: Epitomata $(1497)^{35}$, a przede wszystkim Jan Versor: Ouaestiones super libros Aristotelis De caelo et mundo, $(1493)^{36}$, nie zabrakło też dzieła Sermones de eucharistiae sacramento $(1498)^{37}$, którego autorstwo jest przypisywane „Pseudo-Albertowi Wielkiemu". Henryk Quentell figuruje w omawianym zbiorzc inkunabułów szczyrzyckich jako wydawca wspomnianych wyżej wybitnych uczonych uniwersytetu w Kolonii, tj. Jana Versora i Gerarda de Harderwycka.

Bez wątpienia, najwiçcej spośród zgromadzonych inkunabułów w bibliotece klasztornej, przypada na ośrodki typograficzne w Strasburgu i Norymber- 
dze. I chociaż Strasbourg był obok Włoch głównym dostawcą wydawnictw z zakresu prawa kanonicznego i rzymskiego (Jan Grüninger), a ponadto edycji Ojców Kościoła ${ }^{38}$, to w zbiorze inkunabułów biblioteki szczyrzyckiej typografie Grüningera reprezentuje wyłącznie dzieło Jakuba z Voraginy: Legeda aurea $(1496)^{39}$. Nie sposób też pominąć oficyny Marcina Flacha, specjalizującej się w wydawaniu dzieł z zakresu teologii praktycznej. W zbiorze szczyrzyckim reprezentowana jest przez dzieła: Jana de Lapide, Resolutorium dubiorum, (1494) ${ }^{40}$, oraz Mikołaja z Błonia, De Sacramentis, $(1496)^{41}$. Najprężniejszą ze strasburskich oficyn, najliczniej zresztą reprezentowaną w omawianym zbiorze jest oficyna Jerzego Husnera, występującego w literaturze przedmiotu jako „Typographus Iordani”. Biblioteka klasztorna w Szczyrzycu, posiada 7 dzieł tego zasłużonego typografa strasburskiego. Są wśród nich dzieła: Grzegorza I Wielkiego, papieża; Pastorale $(1496)^{42}$, Mikołaja z Błonia: De Sacramentis $(1487)^{43}$ poczytne, często wznawiane dzieło tamtych czasów, wspomniana już Legenda aurea; Jakuba z Voraginy, wydana w $1487 \mathrm{r}^{44}$, oraz jedno z najwybitniejszych drukowanych dzieł historycznych piętnastowiecznej Europy Historia scholastica Piotra Comestora, którego druk ukończono po 24 II $1485 \mathrm{r}^{45}$. Ważnymi ośrodkami typograficznymi reprezentowanymi w zbiorze, są również: Augsburg i Lipsk. To właśnie z typografii augsburskiej Güntera Zainera pochodzi najstarszy inkunabuł, przechowywany w zbiorach, a jest nim wspomniana wcześniej Margarita Davidica (ca 1475/6), oraz pozostałe trzy inkunabuły, których data ukończenia druku przypada również na rok 1476. Opuściły one prasy drukarskie Antoniego Sorga ${ }^{46}$ Wśród licznie reprezentowanych druków typografii niemieckich w zbiorze szczyrzyckich inkunabułów, nie podobna było by pominąć jednego $\mathrm{z}$ najprężniejszych ośrodków drukarskich piętnastowiecznej Europy-Norymbergii.

Podobnie jak ze Strasburgiem, Kolonią czy Lipskiem, łączyły Polskę z Norymbergia ścisłe związki handlowe, artystyczne i kulturalne. Penetracja tego ośrodka na polski rynek księgarski znajdowała też osobny kanał przez filie Antoniego Kobergera, licznie zakładanych na ziemiach polskich. ${ }^{47}$ Druki tego znakomitego i prężnego typografa-przedsiębiorcy, są zdecydowanie najliczniej prezentowane w bibliotece szczyrzyckiego klasztoru. Z jego oficyny pochodzą m.in. dzieła Angelusa de Clavasio: Summa Angelica de casibus conscientiae, wydane w 1488 r. oraz w 1492; estetyczne wydanie Biblii Mikołaja z Lyry, $(1497)^{48}$, Wincentego Ferreriusa: Sermones de tempore et de sancitis, $(1486)^{49}$; papieża Piusa II,: Epistalae familiares $(1486)^{50}$ i wreszcic psałterze, bez których trudno byłoby sobie wyobrazić bogatą cysterską liturgię. 
Obok licznie występujących druków pochodzenia niemieckiego, drugie miejsce zajmują księgi, które opuściły włoskie oficyny wydawnicze. Piętnastowieczna Italia ze swoimi prężnymi ośrodkami drukarskimi - wśród których poczesne miejsce w omawianym zbiorze, zajęła Wenecja która w sposób niekwestionowany oddziaływała na ówczesną kulturę Polską ${ }^{51}$. Zdumiewa nieco fakt, iż nie mniej prężny ośrodek włoski - jakim był Rzym i Padwa zaledwie reprezentowany jest przez pojedyncze typografie. Ośrodek wydawniczy w Wenecji jest reprezentowany w zbiorach szczyrzyckich przez 9 typografii, spod pras których wyszło łącznie 12 druków. Drugie miejsce z niewspółmiernie mniejszą liczbą druków zajmuje Rzym - jedna oficyna wydawnicza prężnego Stefana Plancka - i jego dwa druki. Dzicła przez nicgo tłoczone to w znakomitej większości mowy i listy okolicznościowe, formularze i bulle, które bez wątpienia były wynikiem silnego związku wymienionej typografii z Kurią Rzymską. W zbiorze inkunabułów szczyrzyckich druki Plancka to jedynie dwa różne wydania Formularium Procuratorum, $(1491)^{52}$ oraz Formularium Instrumentorum (1495) ${ }^{53}$. Podobnic i ośrodek typograficzny w Padwie, reprezentowany jest w bibliotece szczyrzyckiej jedynie przez oficynę Mateusza Cerdonisa, spod której pras drukarskich wyszło dzieło: św. Augustyna Aureliusza. Sermones de vita clericorum (1484) ${ }^{54}$, przechowywane do dzisiaj w klasztornej librarii.

Znacznie więcej uwagi, z oczywistych zresztą względów, nalcży się księgom, które opuściły prasy drukarskie Wenecji. Jak zostało już wspomniane inkunabuły szczyrzyckie pochodzą łącznie z 9 oficyn weneckich, w tym oficyna Boneta Locatella reprezentowana jest przez 3 druki. Produkcję wydawniczą tego typografa cechowała m.in. usługowość na rzecz starej scholastyki, która utrzymywała się na północy Włoch, zwłaszcza w Padwie, gdzie dominował tomizm, scotyzm i awerrioryzm ${ }^{55} \mathrm{~W}$ zbiorze inkunabułów szczyrzyckich tę właśnie oficynę wydawniczą reprezentują dzieła: Jana Dunsa Szkota: Ouaestiones in Universalia Porphyrii $(1492)^{56}$, oraz Ouaestiones in Aristotelis Metaphisica (1497) ${ }^{57}$. Typografie weneckie reprezentuja ponadto Mikołaj de Francofordia z dziełem Angelusa de Clavasio Summa angelica... (1487); Jan de Hallis Officium Beatae Mariae Virginis, (1486) - dzieło i oficyna było już wcześniej omawiane; Otinus de Luna: z dzicłcm Paulusa Venetusa Nicolettiego: Summula logicae (1498); Reynoldus dc Novimagio, Albertus Magnus: De intellectu et inteligibili (1481), Hieronim de Paganinis, wydawca dzieła Trombetty Opus doctrinae Scoticae in Thomistas (1493), jego brat Paganinus de Paganinis, wydawca Angelusa de Clavasio, Summa angelica... (1499), i Baptisty de Salis, Summa casunum conscien- 
tiae (1499). Oficyny weneckie (podobnie jak i rzymskie), były głównymi dostawcami na rynek europejski dzieł pisarzy starożytnych, licznych wydań klasyków, humanistów, a także dzieł prawniczych. W bibliotece szczyrzyckiej nie brakło słynnego dzieła Cycerona De oratore (1485), które opuściło prasy drukarskie Andrzeja Torresanusa ${ }^{58}$, a także monumentalnego dzieła z zakresu prawa: Liber sextus Decretalium ${ }^{59}$ papieża Bonifacego VIII. Wydawcą był typograf wenecki Baptista de Tortis, specjalizujący się m.in. w wydawaniu dzieł $\mathrm{z}$ dziedziny prawa cywilnego i kanonicznego.

Kończący ,geograficzny" przegląd ośrodków i oficyn typograficznych reprezentowanych w zbiorze inkunabułów szczyrzyckich, wspomnieć należy również o piętnastowiecznej Szwajcarii (Helvetia), oraz jej ważnym ośrodku drukarskim - Bazylei, która również odegrała doniosłą rolę w dorobku typograficznym ówczesnej Europy. Bazylejskich typografów reprezentują w omawianym zbiorze: Jan Amerbach, drukiem Jana Kasjana: De institutis coenobiorum (po 1485) ${ }^{60}$, Mikołaj Kessler, dwoma dziełami, jakże zresztą istotnymi, tak $z$ uwagi na treść $w$ nich zawartą jak i samych autorów; są to: Bernard z Clairvaux i jego dzieło: Sermones de tempore et de sanctis, $(1495)^{61}$ i Piotr Lombardus: Sententiarum libri quattuor $(1498)^{62}$. Zaś jedyne w zbiorach dzieło Jana z Verdeny: Sermones Dormi Secure de tempore et de sanctis (1489), opuściło prasy oficyny bazylejskiej Bertolda Ruppela, która w literaturze przedmiotu określana jest jako „Typographus Meffret”.

Interesująco przedstawia się również analiza treściowa inkunabułów biblioteki szczyrzyckiej zasygnalizowana już przy omawianiu ośrodków wydawniczych ówczesnej Europy i drukach reprezentatywnych dla poszczególnych oficyn. Jest rzeczą oczywistą że biblioteki klasztorne w pierwszej kolejności gromadziły księgi związane z liturgią Mszy Św., konieczne do spełniania służby Bożej, tj. Pismo Św., liczne jego komentarze. A zatem nie dziwi fakt posiadania w zbiorze licznych mszałów, lekcjonarzy, antyfonarzy, graduałów czy psałterzy. Wraz ze wzrostem zainteresowań oraz wymogów stawianych zakonnikom przez ich władze zwierzchnie w zakresie wykształcenia, wzrosło też zapotrzebowanie na określonych autorów i ich dzieła. To, co zapewne jest oczywiste i charakterystyczne dla omawianego zbioru XV - wiecznych ksiąg biblioteki klasztornej w Szczyrzycu, to fakt, iż sporo jest dzieł tematycznie związanych z liturgią Mszy Św. Była ona szczególnie bogata zawsze u Cystersów. Odnajdujemy więc w zbiorze psałterze, officjum do Matki Bożej, a także dzieła starożytnych Ojców Kościoła m.in. Kasjana, św. Augustyna Aureliusza, czy papieża Grzegorza Wielkiego. Problematykę prawniczą reprezentują m.in. dzieła: Ange- 
lusa de Clavasio, papieża Bonifacego VIII, Gracjana, a także pisma Kurii Rzymskiej, czy Gesta Romanorum.

W rzędzic wybitnych autorów z okresu rozkwitu scholastyki, spotykamy dzieła: św. Bonawentury, lub uchodzące za takowe (Pseudo-Bonawentury), Dunsa Scota, kończącego okres klasyczny a także św. Alberta Wielkiego i uchodzące za jego dzieła (Pseudo-Alberta Wielkiego). Na uwagę zasługuje bardzo popularny w swojej epoce podręcznik dla kapłanów, tzw. Manipulus curatorum Gwidona de Monte Rocherii, oraz najsłynniejsze i najbardziej rozpowszechnione dzieło $z$ zakresu teologii spekulatywnej, scholastyczny zbiór sentencji, który stał się podstawą dla wykładów teologii w całym późniejszym średniowieczu, czyli: Sententiarum Libri IV Piotra Lombarda.

W zbiorze inkunabułów szczyrzyckich zwraca uwagę bogata literatura z zakresu kaznodziejstwa, a także sztuka ich wygłaszania. Ze znanych autorytetów w tej dziedzinie nie zabrakło dzieł: „doktora miodopłynnego", św. Bernarda z Clairvaux jednego z zakonodawców Cystersów, a także św. Bernardyna ze Sieny, Gabriela Bielą, Wilhelma Paryskiego, wybitnego kaznodziei zakonu dominikańskiego - Wincentego z Ferrary, czy niemniej znakomitego Mikołaja z Błonia, zwanego „Pszczółką”.

W dziedzinie historiografii kościelnej klasztor posiadał najbardziej popularne w XV wieku dzieło Piotra Comestora wspomniana już: Historię scholastycznq używaną przez całe niemal średniowiecze jako podręcznik historii biblijnej. Poza tym dziełem, historiografia kościelna w szczyrzyckim klasztorze reprezentowana jest przez wybitnego autora literatury hagiograficznej, wymienionego wcześniej Jakuba z Voraginy, autora najpoczytniejszego dzieła z gatunku ,żywotów” i „cudów”, tzw. Legenda aurea, znanej także pod nazwą Historia Lombardica.

Oczywiście, tych kilka uwag nie wyczerpuje omówienia zawartości treściowej szczyrzyckich inkunabułów. Jest ona w niniejszym wstępie tylko zasygnalizowana. Autorzy, ich dzieła i zawarta w nich treść będą szerzej omawiane w pracy poświęconej bibliotece szczyrzyckiej.

\section{PROWENIENCJE I GLOSY MARGINALNE INKUNABUŁÓW SZCZYRZYCKICH}

Inkunabuły biblioteki ojców Cystersów w Szczyrzycu, są jednolitym proweniencyjnie zbiorem ksiag, historycznie związanym z jednym miejscem. Na wszystkich drukach widnieje dobrze znany wpis potwierdzają- 
cy przynależność woluminu do biblioteki klasztornej: „Ex libris Fratrum Monasterij Ciricensis”, „Ex Libris Monasterij Ciricensis”, czasami też zapis: „Liber Monasterij Ciriceusis”, bądź: „Liber Monasterij Vallis Mariae Ciricensis”, czy: „Conventus Ciricensis S.O. Cisterciensis”. Wszystkie te wpisy uczynione odręcznie, potwierdzają fakt, iż w II połowie XVII wieku, był zapewne przeprowadzany w klasztorze spis jego zasobności, a zatem obejmował on też księgi, które niosły w sobie nie tylko bogactwo treści, ale również miały wymierną wartość materialną. Z początkiem wieku XIX i I poł. XX w. księgi te ponownie spisywano. Poświadczają ów fakt zachowane w klasztorze archiwalia i nade wszystko inwentarze biblioteczne. Po ostatniej zapewne inwentaryzacji, przeprowadzonej już w XX wieku, książki w bibliotece zostały sygnowane owalną pieczęcią z dobrze widocznym napisem otokowym: „Biblioteka oo. Cystersów w Szczyrzycu”.

Jednakże najciekawsze z punktu historycznego są wpisy proweniencyjne indywidualnych osób, często bardzo znamienitych i zasłużonych dla nauki i kultury polskiej, jak choćby wpis własnościowy Wojciecha z Brudzewa na dziele Piotra Comestora: Historia scholastica, (poz.56), czy bpa Mikołaja Szyszkowskiego, na kartach: Sermones de laudibus sanctorum Roberta Carraciolusa, (poz. 22).

Kilka inkunabułów nosi ślady proweniencji opatów i przeorów szczyrzyskich. A zatem można domniemywać, iż, być może oni to właśnie bądź za ich rządów opackich w Szczyrzycu nabywano księgi do biblioteki klasztornej. Są wśród nich opaci: Piotr III Borowski (1565-1590), Stanisław Bukowiecki (1561-1565), Joachim Cieniawski (1592-1607), Stanisław Drohojowski (1607-1632), jest także Jan Weynrich, opat w klasztorze mogilskim w latach (1503-1522).

Na wielu inkunabułach widnieją wpisy proweniencyjne „skrybów” zakonnych owi ,fratres ciriciensis" są w zasadzie dobrze udokumentowani historycznie. Często obok swego imienia i nazwiska na kartach księgi wpisywali "frater scriptura", jak choćby brat Helias Grabowski, zaś jego konfrater, niejaki Malachiasz, na dziele Jana Kasjana De institutis coenobiorum - obok swego imienia, zapisał ,przepetniony będqc pokora” (?) „Frater Malachias Indignus 1696”. Ow Malachiasz „Niegodny”, jak potwierdzają to kroniki i dokumenty zakonne, to nikt inny, jak Malachiasz Dzierzkowski, późniejszy podprzeor w Szczyrzycu (1699 r.), prowizor, w końcu przeor tegoż klasztoru, którą to funkcje sprawował od 1719 roku. Wedle reguły zakonodawcy mnich nie może posiadać dóbr materialnych na własność - wyjątków nie było też dla ksiag, być może wyłączywszy brewiarze. A zatem zdumie- 
wa fakt, iż bądź co bądź na dziele Cycerona De oratore etc... pod datą: 1552 - zanotowano: „Hic liber frater Ambrosius” (poz. 25). Na kilku inkunabułach zachowały się też wpisy proweniencyjne informujące, kiedy, kto i za jaką kwotę nabył księgę. A więc dzieło Jana Głogowczyka Exercitum super omnes... za 25 srebrnych groszy nabył Szymon z Krakowa, magister sztuk wyzwolonych, rektor przy kościele św. Krzyża w Krakowie (1553). Tenże sam Szymon był również nabywcą dzieła Paulusa Venetusa Nicolettiego: Summula logicae... a wpis w pełnym brzmieniu: „Iste liber emptus 40 grss., per me Simonem de Cracovia, Artium liberalium baccalarium" w pełni ów fakt potwierdza ${ }^{63}$.

Szczyrzyckie inkunabuły noszą również ślady wpisów proweniencyjnych nie tylko zakonników, jest wśród nich ,parochus” z Wilkowiska, Szymon Basteczka ${ }^{64}$, Anzelm Kuśmiderowicz, wikary w Tymbarku, proboszcz w parafii Wilkowisko ${ }^{65}$, czy Walenty Jendrosch z Goduszy, „Minister Sancti Ecclesiae Ioannis in Gora Szczirzycka" ${ }^{\prime \prime 6}$.

Wiele proweniencji jest trudnych bądź niemożliwych już do odczytania, z uwagi na duży stopień zniszczenia kart, na których je zapisano. Często też owe wpisy własnościowe zostały po prostu celowo zamazane, być może przez kolejnych właścicieli. Utrudnia to nie tylko odczytanie treści wpisu proweniencyjnego, ale jest wielką stratą do poznania dalszych losów ksiąg, ich właścicieli, a w końcowym efekcie historii opisywanego zbioru.

Kilka uwag należy się również glossom czy tzw. uwagom marginalnym, one również zostały zasygnalizowane przy opisie poszczególnych woluminów. Mają zatem niepodważalną wartość historyczną i poznawczą. Podano ich krótkie omówienie, sygnalizujące w przybliżeniu ,powstanie”, bądź ewentualnie treść, o ile ta była możliwa do odczytania. Owe glosy marginalne, są prawdziwym bogactwem, omawianych inkunabułów. Potwierdzają dobitnie fakt, iż księgi owe czytano, a swoje przemyślenia, uwagi, komentarze w stosunku do przeczytanego tekstu, zapisywano na marginesach woluminu. Daje to pewien obraz umysłowości ludzi, którzy sięgali po te księgi, ich wrażliwości na słowo i potrzebę czerpania z nich wiedzy.

$\mathrm{Na}$ wielu kartach notowano ,jakieś” gospodarskie informacje, dotyczące m.in. własności dóbr szczyrzyckich, czy dosyć zabawne wierszyki, jak choćby ten zapisany w dziele Kasjana De institutis coenobiorum, a zaczynający się od słów: „Tym się bynajmniej sława ma nie psuje...”. Zapisywano też całe zdarzenia, różne osobiste przeżycia, jak choćby sugestywny opis przetrwania potężnej burzy w dniu 9 maja 1731 roku, przez niejakiego księdza Tyrpińskiego w lesie stryszawskim, koło Lanckorony. „Lek- 
tura" tego opisu może obecnie wywoływać lekki uśmiech, lecz jakże wielkie musiało być to przeżycie dla tego człowieka, skoro zapisał owo zdarzenie aż dwukrotnie (!) na kartach dzieła Roberta Caracciolusa: Sermones de laudibus sanctorum. Księgi te były rzeczywiście czytane a ich oddziaływanie pozostawiało widoczny ślad w psychice czytelnika zakonnego, o czym może świadczyć kolejny przytoczony przykład. Otóż na dziele, którego autorem był Eneasz Sylwiusz Piccolomini, późniejszy wybitny zresztą papież Pius II: Epistolae familiares, poza widoczną „obfitą glosą marginalna", prawdopodobnie pochodzącą z XVI wieku, na oprawie przedniej verte, widnieje odręczny wpis o jakże sugestywnej treści: „Sq tu obrzydliwe listy z czasów, kiedy byl świeckim". Uwagę tę uczynił, opat szczyrzycki Benedykt Biros (1937 - 1958), wybitna i nietuzinkowa osobowość w dziejach opactwa w Szczyrzycu.

Owe glossy, liczne sentencje, uwagi dotyczące treści tekstu, fragmenty utworów wierszowanych, modlitw a nawet ,próby" sporządzenia kalendarzy są nieocenionym źródłem historycznym, będąc również znakomitym studium psychologicznym osób, które zapisywały w potrzebie chwili „stany swojej duszy i umysłu". Inkunabuły szczyrzyckie z nielicznymi tylko wyjątkami są po prostu „zapisane”, dziś powiedzielibyśmy zaczytane. Doskonały to zatem materiał do dalszych, żmudnych badań i dociekań historycznych, nad umysłowością tych wszystkich, którzy przed wiekami z owych ksiag czerpali wiedzę, natchnienie do dalszej pracy i modlitwy.

\section{ZDOBNICTWO I OPRAWY INKUNABUŁÓW SZCZYRZYCKICH}

Forma książki drukowanej w pierwszych dziesiątkach lat XV wieku, jest bardzo zależna od powszechnie przyjętej i uznanej formy rękopisu. Zależność ta widoczna jest zarówno w ogólnym układzie książki, wzorowanym na księdze rękopiśmiennej, kompozycji strony a także w dziedzinie ilustracji. Szeroko pojęta ,ilustracja" czy raczej zdobnictwo piętnastowiecznych ksiag, obejmowały malarstwo miniaturowe, $\mathrm{z}$ reguły stosowane w luksusowych księgach liturgicznych ${ }^{67} \mathrm{Są}$ to $\mathrm{m}$.in.: marginalne floratury i bordiury, kolorowany drzeworyt bądź inicjał wówczas ręcznie jeszcze domalowywany, zwany uncjalnym, bądź lombardem, domalowywane ręcznie inicjały czerwone, niebieskie bądź zielone oraz rubryki, takie jakie występowały jeszcze powszechnie w księgach rękopiśmiennych.

$\mathrm{Na}$ wielu kartach inkunabułów pozostawiano jeszcze puste miejsca na przewidziane przez iluminatora inicjały, często w środku takiego pola 
odbijano małą drukowaną literkę, tzw. reprezentant. będący wskazówką dla rubrykatora czy iluminatora jaki inicjał ma w danym polu umieścić. W zasadzie wszystkie te pobieżnie zasygnalizowane elementy zdobnictwa książki piętnastowiecznej występują w omawianym zespole szczyrzyckich inkunabułów.

Szczyrzyckie inkunabuły, bogate w cenne wpisy proweniencyjne i glosy marginalne nie należą do zespołu odznaczającego się szczególną sztuką zdobienia poszczególnych kart. Zachowane tzw. inicjały uncjalne wykonane ręcznie, nie „wzbijają" się na wyżyny kunsztu artystycznego ich autora. Widoczny w ich wykonaniu „pośpiech ręki” świadczyć może i o tym, iż wykonywany mógł być tzw. „sposobem domowym”, czyli prawdopodobnie w samym klasztorze, przez mnicha, który posiadał „względną" sztukę zdobienia i niewyszukany „smak artystyczny”. Inicjały uncjalne, iluminowane bogatą ornamentyką floraturową występują zaledwie w kilku woluminach. Najczęściej jednak są to tzw. „małe inicjały”, również domalowane czerwoną niebieską bądź zieloną farbą. Tekst na wzór dawnych kodeksów rękopiśmiennych bywa rubrykowany, zaś w miarę rozwoju sztuki typograficznej i ilustracyjncj zdobnictwo ręczne, zastępują inicjały drzeworytowe, czasami już kolorowane.

Kilka spośród szczyrzyckich inkunabułów posiada kartę tytułową z pięknie zakomponowanym drzeworytem, przedstawiającym wizerunki świętych, bądź sceny nauczania, ale należą one do rzadkości. Dopiero wiek XVI w pełni wykorzysta artystyczne wizje wybitnych mistrzów sztuki drzeworytniczej. Bowiem dla czytelnika schyłku epoki XV i początku XVI wieku, biorącego do ręki książkę, znajdujące sį̨ w niej ilustracje i wszelkie elementy zdobnicze, stanowiły nie tylko materiał kształcący, ale nade wszystko stawały się źródłem wzruszeń estetycznych wzbogacających przeżycia duchowe.

Kilka uwag należy się również oprawom szczyrzyckich inkunabułów. Nie ma wśród nich opraw tzw. „mniszych" czy „sakwowych”. W większości są to oprawy „późniejsze" niż same dzieło. Najstarsze inkunabuły w większości zachowały oprawę oryginalną z pierwszej połowy XVI wieku. W znakomitej większości oprawę ksiąg szczyrzyckich stanowi deska bukowa lub lipowa, na którą „,naciągnięto” białą bądź brązową skórę. Spotkać można natomiast oprawy, których skórę barwiono na kolor czarny lub bordowy. Kilkanaście spośród opraw nosi cechy wyraźnie renesansowe. Powierzchnia oprawy podzielona jest na pole środkowe, czyli tzw. „zwierciadło” i otaczające je obramowania. Narożniki przedniej i tylnej oprawy ozdabiają ochronne, kunsztowne mosiçżne okucia, na przednim i tylnym licu oprawy zacho- 
wał się tzw. „guz środkowy”. Wiele spośród inkunabułów zachowało oryginalne klamry, jedną bądź dwie, na które dla ochrony zamykano przed wiekami owe foliały. Czasami widoczne są też wiązania przy oprawie, bądź ledwo widoczne ich fragmenty. Niektóre spośród zachowanych opraw, bogatsze o „figuralną lub zwierzęcą ornamentykę" były przykładem ciekawego zdobnictwa XVI - wiecznych mistrzów sztuki introligatorskiej, którzy czasami pozostawali „,wycisk introligatorski daty” - informujący kiedy ową księgę oprawiano. Przykładem jest choćby oprawa dzieła Alberta Wielkiego De natura... (1493) z widocznym wytłokiem daty: „1558” i Sceną Ukrzyżowania na przednim licu oprawy ${ }^{68}$. Piękną oprawę zachowało m.in. dzieło Angelusa de Clavasio Summa angelica... (1487) ${ }^{69}$, Arystotelesa De anima... (1491), $\mathrm{z}$,wyciskiem introligatorskim" postaci Świętych Pańskich w zwierciadle przedniego lica oprawy ${ }^{70}$. Bez wattpienia, jedną z ciekawych opraw w zbiorze inkunabułów szczyrzyckich, posiada Legenda aurea Jakuba de Voragine - wydanie strasburskie z $1486 \mathrm{r}^{71}$, i to bynajmniej nie tylko $\mathrm{z}$ uwagi na typowy przykład oprawy późnorenesansowej, ale nade wszystko na widoczny i dosyć dobrze zachowany superexlibris herbowy z monogramami „J.C.A.C” - „Joachimus Cieniawskij Abbatis Ciricensis". A zatem to popularne w swojej epoce dzieło zapewne musiało być własnością 33 opata szczyrzyckiego, Joachima Cieniawskiego, postaci „,barwnej i nieco kontrowersyjnej" ${ }^{2}$, którego trudno byłoby podejrzewać o wielkie zamiłowanie bibliofilskie. Fakt jednakże pozostaje faktem i opat Joachim Cieniawski zapewne zupełnie nieświadomie ,wpisał się w ciąg dziejów biblioteki opactwa szczyrzyckiego”. Wiele spośród zachowanych opraw jest „sporządzonych” jakby nieco „oszczędnym" sposobem. Wolumin posiada jedynie skórę naciagnniętą do połowy deski, czasem na grzbiet oprawy. Poszczególne składki starej księgi wzmocnione są paskami pergaminowymi, pochodzącymi ze starych, niepotrzebnych zapewne ksiag rękopiśmiennych, w wielu przypadkach z dobrze zachowanym tekstem bądź notacją muzyczną dawnego antyfoniarza lub graduału.

Ów fakt niezbicie świadczy o tym, iż w dawnych wiekach opiekujący się klasztorną biblioteką mnich cysterski starał się sobie znanym tylko sposobem poddać stare księgi „opiece konserwatorskiej”, przedłużając ich „kruchy żywot”. Owe wklejki pergaminowe są również znakomitym źródłem do poznania dziejów biblioteki opactwa jak również mentalności osób, które w określonym czasie historycznym tworzyły wspólnotę zakonną. Bowiem wiele pośród kart wzmacniających starą piętnastowieczną księgę, pochodzi zwyczajnie z zapisów kroniki klasztornej, a te jak wiadomo są nadal niewyczerpanym i arcyciekawym źródłem poznawczym minionego czasu. 
Kilka inkunabułów posiada oprawę wtórną. $Z$ reguły na taką właśnie oprawę zużywano karty pochodzące $z$ dawnych antyfoniarzy cysterskich, gdzie do dzisiaj widoczny jest jeszcze zapis notacji muzycznej gotycką neuma. ${ }^{73}$

Ten arcyciekawy i bogaty zespół XV-wiecznych ksiag klasztoru Opactwa oo. Cystersów w Szczyrzycu, w miarę dobrze zachowany, jest świadectwem umysłowości pokoleń, dzięki którym powstawał, był ochraniany, służąc człowiekowi i jego dążeniom w poznawaniu tajników duszy i spraw doczesnych przez kilka pokoleń. Naznaczony "piętnem" bolesnego i pięknego upływu czasu, „był świadkiem” wielu ważnych i trudnych zdarzeń historycznych, które nie ominęły to jedno $z$ najmniejszych opactw cysterskich na polskiej ziemi. Służył mnichom nie tylko klasztoru szczyrzyckiego. Ochraniano te księgi, lecz i w razie potrzeby, były powiernikami ludzkiej duszy i chwili, która ,nakazała" niejako ów stan ducha i umysłu, uwiecznić na marginesach i oprawach starych ksiąg. Darowane, przekazywane bądź nabywane w rozmaity sposób noszą do dziś ślady ludzkiego w nim obcowania.

Autorka niniejszego artykułu przygotowuje w chwili obecnej do druku katalog inkunabułów biblioteki oo. Cystersów w Szczyrzycu, a także zarys dziejów biblioteki szczyrzyckiej.

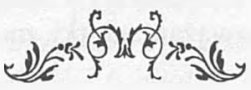

Przypisy:

1 Na temat biblioteki, a właściwie tylko niektórych spośród jej zbiorów publikował m. in. ks. R. Nir w ABiMK T. 37: 1978, s. 234 - 248, opisując jedynie zasób rękopisów muzycznych w bibliotece oo. Cystersów w Szczyrzycu; powstała też praca dotycząca druków medycznych autorstwa L. Chrzęściewskiego, pt.: Druki psychiatryczne w zbiorach Biblioteki Szczyrzyckiej, opublikowna w skrócie w Archiwum Historii Medycyny 1975, T. 38, z. 2. s. 151-152. Również i publikacje z okresu międzywojennego autorstwa K. Piekarskiego, skupiająjedynie swoją uwagę na wycinkowym fragmencie zbiorów biblioteki, tj. inkunabułów i niektórych poloniców. Do chwili obecnej Biblioteka nie doczekała się w miarę wyczerpującego opracowania. A. Kawecka-Gryczowa, Wstepp do: „Incunabula quae in Bibliothecis Poloniae asservantur," T. 1. Wrocław 1970. Po dokladnej analizie i porównaniu autorka niniejszego opracowania wykazała pewne rozbieżności, zaistniałe w stosunku do IBP; np. dotyczy to poz. 3 ( Inc. 3 adl. 1 T. IV.7) - Pseudo-Albertus Magnus: De duabus... Wolumin ten nie został ujęty w katalogu IBP, mimo, iż znajduje się w bibliotece klasztornej. Ponadto rozbieżności dotyczą również inkunabułów w: poz. 26 (Inc. 57 adl. 2 T. IV. 13), poz. 27 (Inc. 57 adl. 1 T. IV. 13), poz. 54 (Inc. 57 T. IV. 13 ), poz. 73 (Inc. 57 adl. 4 T. IV. 13). ${ }^{3}$ G. Kowalski O. Cist., Katalog Inkunabulów Biblioteki Opactwa Mogilskiego oraz Katalog Inkunabulów Biblioteki Klasztoru cystersów w Szczyrzycu. Kraków 1915. 3. IX t 
4 - patrz: „Biblioteka Warszawska” 1850. T. 3. s. 193-224; Autorzy wspomnianego opracowania. J. Lepkowski i J. Jerzmanowski niestety nie podają wiarygodnej podstawy historycznej, na której oparli swoje twierdzenie, jakoby część zbiorów biblioteki szczyrzyckiej miała trafić po 1794 r. do biblioteki tarnowskiego seminarium Odnosi się wrażenie, że informacja taka była „zasłyszana” a jest to niewątpliwie zbyt mało wiarygodne źródło (o ile w ogóle jest !) by móc je w pełni przytaczać. Autorka niniejszej publikacji, opracowując bibliotekę tarnowskiego Seminarium, nie natknęla się na żadną książkę z wpisem własnościowym opactwa cystersów w Szczyrzycu - a zważywszy, że biblioteka cystersów była w II poł. XVII w. inwentaryzowana. a co za tym idzie, na każdej z ksiag umieszczono wówczas wpis własnościowy, toteż dzięki tym wpisom łatwo z ogólnego zasobu bibliotecznego, uchwycić księgi pochodzące ze Szczyrzyca. Niestety takowych brak. Nie zachowały się równieź żadne akta konsystorza biskupiego w Tamowie wskazujące na przejęcie do Tamowa części biblioteki szczyrzyckiej. Brak jest również jakiejkolwiek wzmianki w archiwum oo. Cystersów w Szczyrzycu. A więc wniosek wysuwa się dość jasny: nic ma pełnej, wiarygodnej podstawy, by móc dać osąd historyczny w pełni udokumentowany, o przyjęciu części biblioteki szczyrzyckiej do biblioteki Seminarium Duchownego w Tarnowie: nie ma również innych zbiorów biblioteki szczyrzyckiej w Tarnowie.

${ }^{5}$ R. Witkowski, Biblioteki opactw cysterskich na ziemiach polskich i dawnej Rzeczpospolitej. Zarys problematyki i stan badań, w: „Monasticon Cisterciense Poloniae”. T.1. Poznań 1999. s. 1646 K. Piekarski., Uwagi i uzupelnienia do katalogu inkunabulów mogilskich. Kraków 1924

${ }^{7}$ Op. cit.. s. 3

${ }^{8}$ Op. cit., s. 4

${ }^{9}$ Błędy i uchybienia, które wykazał K. Piekarski w swojej recenzji poświęconej Katalogowi nie są przedmiotem wnikliwych rozważań autorki, można je skonfrontować z publikacja; patrz przypis 6.

${ }^{10}$ Patrz przypis 2.

" Notatka sporządzona przez o. Antoniego Gucwę na podstawie listów otrzymanych z Biblioteki Jagiellońskiej, znajduje się obecnie w Archiwum i Bibliotece oo. Cystersów w Szczyrzycu (bez numeru).

12 Powyższa informacja dotyczy m.in.inkunabułów ujętych w IBP pod poz. 745. 2103

${ }^{13}$ Tzn. Katalogu Kowalskiego (Kow Sz) i Centralnego Katalogu Inkunabulów Polskich (IBP)

${ }^{14}$ B O.Cist. Szcz. Inc. 50 T.II.8; poz. 47

${ }^{15}$ Krótka notka biograficzna dotycząca osoby J. K. Bańkowskiego zawarta jest w katalogu proweniencji.

${ }^{16}$ B O.Cist. Szcz. Inc. 21 T.III.4. poz. 18

${ }^{17} \mathrm{~K}$. Morajko O.Cist., Organizacja parafialna duszpasterstwa parafialnego prowadzonego przez oo. Cystersów w Szczyrzycu. Praca licencjacka napisana w instytucie Teologicznym w Tarnowie agregowanym do Wydziału Teologicznego PAT w Krakowie. Autor w rozdziale pt.: „Parafie pozaszczyrzyckie $w$ których pracowali Cystersi” - wiele uwagi poświeca m.in. parafii w Górze Św. Jana (s. 171-179) przytaczając cenne dokumenty. w oparciu o które, ta najstarsza, ,placówka" Cystersów szczyrzyckich działała przeszło 700 lat.

${ }^{18}$ B O.Cist. Szcz. Inc. 50 adl. 2 T.II.8; poz. 19

${ }^{19}$ B O.Cist. Szcz. Inc. 50 adl. I T.II.8: poz. 45 


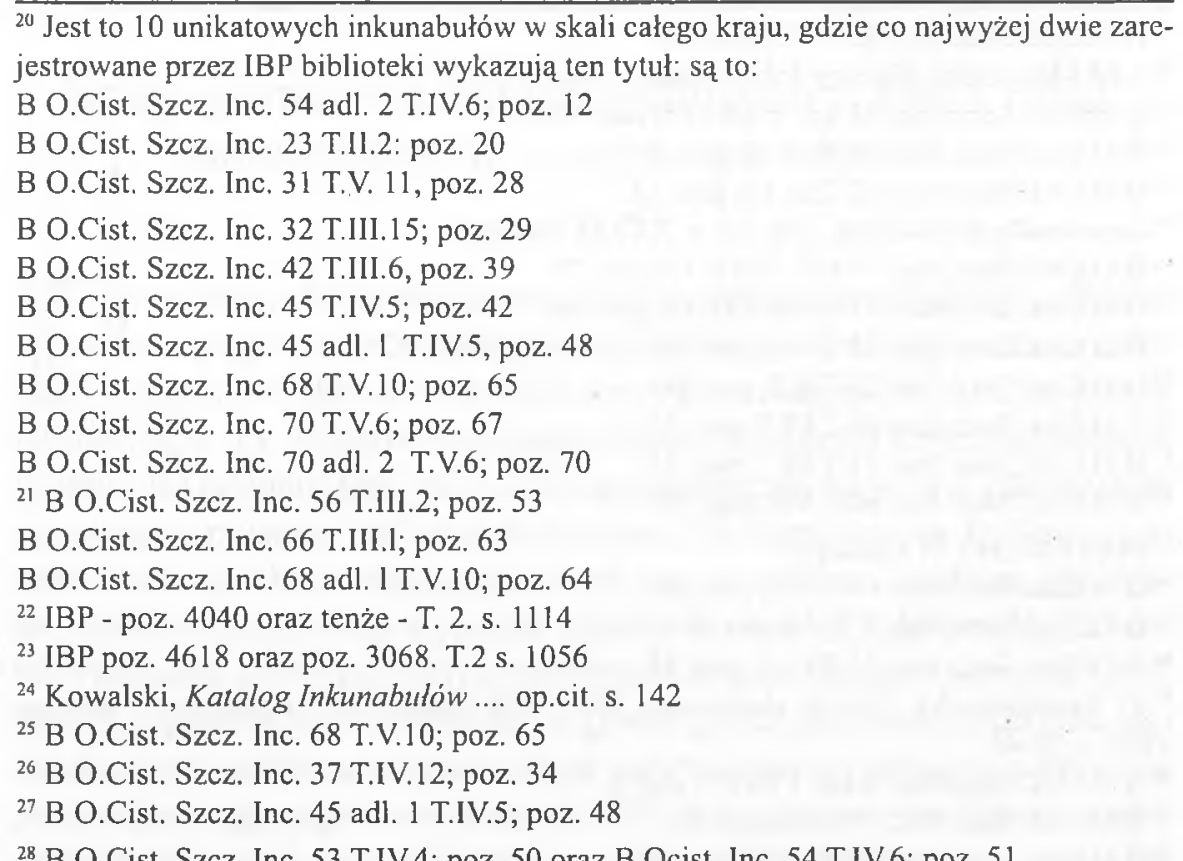

${ }^{28}$ B O.Cist. Szcz. Inc. 53 T.IV.4; poz. 50 oraz B Ocist. Inc. 54 T.IV.6; poz. 51

${ }^{29}$ Informacja i stosowne sprostowanie zawarta autorka w krótkiej nocie, poprzedzającej opis bibliograficzny obu inkunabułów - poz. 50 i 51 w niniejszym katalogu.

${ }^{30}$ Zob. IBP, poz. które wymieniają bibliotekę cystersów w Szczyrzycu.

${ }^{31}$ J.M. Marszalska, Katalog Inkunabulów Biblioteki Wyższego Seminarium Duchownego w Tarnowie. Tarnów 1997. s. 12.; za: Incunabula Biliotheca Poloniae, Warszawa 1972, (WSHP) s. XXXVII - XXXVIII (wstęp)

${ }^{32}$ Incunabula Bibliotheca..., s. XXXVIll (wstęp).

${ }^{33}$ B O.Cist. Szcz. Inc. 10 T.IV.10; poz. 1034 B O.Cist. Szcz. Inc. 11 T.IV.11; poz. 11

${ }^{35}$ B O.Cist. Szcz. Inc. 34 T.IV.8; poz. 31

${ }^{36}$ B O.Cist. Szcz. Inc. 10 adl. 1 T.lV.10; poz. 74

${ }^{37}$ B O.Cist. Szcz. Inc. 53 adl. 2 T.IV.4; poz. 4

${ }^{38}$ Incunabula Bibliotheca..., op. cit. s. XXXVIII (wstęp)

${ }^{39}$ B O.Cist. Szcz. Inc. 4 T.V.9; poz. 41

${ }^{40}$ B O.Cist. Szcz. Inc. 53 adl. 1 T.IV.4; poz. 44

${ }^{41}$ B O.Cist. Szcz. Inc. 54 T.IV.6; poz. 5142 B O.Cist. Szcz. Inc. 35 T.1II.14; poz. 3643 B O.Cist. Szcz. Inc. 53 T.IV.4; poz. 50.

${ }^{44}$ B O.Cist. Szcz. Inc. 43 T.V.8; poz. 40.

${ }^{45}$ B O.Cist. Szcz. Inc. 59 T.III.5; poz. 56.

${ }^{46} \mathrm{Na}$ temat najstarszych (najwcześniejszych) inkunabułów biblioteki szczyrzyckiej była już wcześniej wzmianka. Patrz poz. przypisu 19; 20.

${ }^{47}$ Incunabula Bibliotheca... op. cit. s. XXXVIII (wstęp).

${ }^{48}$ B O.Cist. Szcz. Inc. 75 T.II.10; poz. 16.

${ }^{49}$ B O.Cist. Szcz. Inc. 75 T.V.12; poz. 75 adl. 1 T. V. 12. 


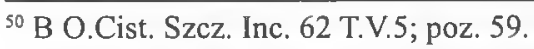

5) J. M.Marszalska, Katalog Inkunabulów..., op.cit s. 13.

${ }^{52}$ B O.Cist. Szcz. Inc. 32 adl. 1 T.III.15; poz. 30.

${ }^{53}$ B O.Cist. Szcz. Inc. 32 T.III.15; poz. 29.

${ }^{54}$ B O.Cist. Szcz. Inc. 52 T.III.15; poz. 12.

${ }^{5 s}$ Incunabula Bibliotheca..., op. cit. s. XXXIX (wstęp).

${ }^{56}$ B O.Cist. Szcz. Inc. 57 adl. 1 T.IV. 13; poz. 27.

${ }^{57}$ B O.Cist. Szcz. Inc. 57 adl. 2 T.IV.13; poz. 26.

${ }^{58}$ B O.Cist. Szcz. Inc. 28 T.V.1; poz. 25.

${ }^{59}$ B O.Cist. Szcz. Inc. 23 T.II.2; poz. 20.

${ }^{60}$ B O.Cist. Szcz. Inc. 26 T.III.3; poz. 23.

${ }^{61}$ B O.Cist. Szcz. Inc. 15 T.III.7; poz. 15

${ }^{62}$ B O.Cist. Szcz. Inc. 60 T.V.3; poz. 57

${ }^{63}$ Patrz poz. 34 i 54 katalogu.

${ }^{64}$ B O.Cist. Szcz. Inc. 64 T.II.6; poz. 61.

${ }^{65}$ B O.Cist. Szcz. Inc. 7 T.V.4; poz. 7.

${ }^{66}$ B O.Cist. Szcz. Inc. 21 T.III.4; poz. 18.

${ }^{67}$ H. Szweykowska, Ksiqżka drukowana XV - XVIII wieku. Zarys historyczny. Wrocław 1980 , s. 60-61.

${ }^{68}$ B O.Cist. Szcz. Inc. 3 adl. 1 T.IV.7; poz. 2.

${ }^{69}$ B O.Cist. Szcz. Inc. 5 T.II.5; poz. 5.

${ }^{70}$ B O.Cist. Szcz. Inc. 10 T.IV.10; poz. 10.

${ }^{71}$ B O.Cist. Szcz. Inc. 43 T.V.8; poz. 40.

72 Patrz indeks proweniencji - nota biograficzna.

${ }^{73}$ Patrz m.in. oprawy: poz. 18, 29, 62, 63, 71. 